\title{
Kill the "Mere Color" Rule: Equal Protection for Color under the Lanham Act
}

\author{
Stephen J. Newman†
}

Courts are used to dealing with words. Lawyers parse sentences, resolve textual ambiguities, create and alleviate tension in language, and tease meaning out of dense syntax. When faced with symbols other than words, however, lawyers and courts frequently forget everything they know. But just as legal minds can determine what a word is, and is to do, they also can determine what nonverbal symbols are designed to do, and can apply that knowledge to bring order to an unsettled area of the law. ${ }^{1}$ This Comment argues that under certain circumstances, courts should permit the limited ownership of a particular type of nonverbal signifier-color-in much the same manner as they permit the limited ownership of what courts understand best-words.

To say that a person may "own" a color under trademark law is somewhat deceptive. When the law declares that a business owns a trademark, all the law says is that no one else may use that trademark when marketing goods or services, if use of the mark would mislead or confuse purchasers as to the true source of what is marketed. Others can still use the trademarked color outside the owner's line of business, where the use of the mark will not deceive customers as to source or sponsorship. Granting Lanham Act protection to color will not result in corporate trademark cops, conducting raids on artists who use "Widgetco Peach," unless the artists are selling widgets. And even if the artists are selling widgets, they probably may use a protected color as long as they do not use it in a manner that would suggest an affiliation with Widgetco, or that would confuse purchasers as to the true source of the widgets. ${ }^{2}$

† A.B. 1992, Harvard University; J.D. Candidate 1995, The University of Chicago.

1 Indeed, the practice of examining nonverbal signifiers has long been recognized as a vital element of First Amendment jurisprudence. See, for example, Texas $v$ Johnson, 491 US 397, 404 (1989) ("The First Amendment literally forbids the abridgement only of 'speech'' but we have long recognized that its protection does not end at the spoken or written word.").

${ }^{2}$ See Michelin Tire Corp. $v$ General Tire \& Rubber Co., 202 USPQ (BNA) 294, 299 (TTAB 1979) (noting that competitors may use trademarked letter, "X," so long as "the 
This Comment argues that trademark law should treat color as it treats other symbols-be they words, numbers, shapes, sounds, or scents. In other words, a producer should sometimes be allowed to claim a distinctive color as his own, and bar others from using it in a manner that could confuse purchasers. Just as color can be used for powerful effect in advertising, it can be used for powerful effect by manufacturers who intend to deceive purchasers into believing that shoddy goods are in fact the wellconstructed goods of another. Because color can be used to misidentify the source of goods, trademark law should protect legitimate use of color, and should allow actions against those who seek to mislead the public.

A trademark allows a purchaser to identify products with a certain manufacturer, or with certain qualities that distinguish the product from other, similar products. Trademarks (or service marks) usually are words ("Kodak"), phrases ("Burger King"), or distinctive designs (the "golden arches" at McDonald's). "Trade dress," the product's overall appearance in the marketplace, also may be protected. ${ }^{3}$ Technology and marketing creativity march on, however, with manufacturers seeking protection of new and unique symbols to signify products and services.

The Patent and Trademark Office has granted trademark protection to certain sounds ${ }^{4}$ and scents. ${ }^{5}$ Some courts, however, have been reluctant to read the broad language of the federal trademark statute, the Lanham Act, ${ }^{6}$ to protect such nontraditional symbols. In NutraSweet Co. $v$ Stadt Corp., the Seventh Circuit held that color alone, without the addition of designs, slogans, or other marketing staples, may never be protected under the Lanham Act. ${ }^{7}$ The court held that to protect "mere color" would upset existing expectations of the scope of the

letter has been so merged or obfuscated in the whole as to create an overall commercial impact unlike that of the letter mark alone").

${ }^{3}$ See Two Pesos, Inc. v Taco Cabana, Inc., 112 S Ct 2753, 2755 (1992) (protecting a restaurant's "Mexican trade dress" described, in part, as "a festive eating atmosphere").

4 See George Gottlieb, "In Case You Missed It . . . , 62 Trademark Rptr 605, 605-06 (1972) (noting, along with other sound trademarks, the registration of "a sequence of chime-like musical notes which in the key of $C$ sound the notes G, E, C"). Even the musically uninclined are likely to recognize this sequence of notes as identifying the National Broadcasting Company, Inc. ("NBC").

${ }^{5}$ See, for example, In re Clarke, 17 USPQ2d (BNA) 1238, 1238-40 (TTAB 1990) (allowing registration of " $\mathrm{a}$ high impact, fresh floral fragrance reminiscent of Plumeria blossoms" as a mark for sewing thread and embroidery yarn).

6 The Trademark Act of 1946,60 Stat 427 , codified as amended at 15 USC $\S \S 1051$ 1127 (1988).

7917 F2d 1024 (7th Cir 1990). 
Lanham Act, promote monopoly, and plunge the courts into intractable questions of color confusion. ${ }^{8}$ The NutraSweet decision directly conflicts with the decisions of the Eighth Circuit ${ }^{9}$ and of the Federal Circuit ${ }^{10}$ (a specialized court that hears many trademark cases). Those circuits have held that the Lanham Act should be read broadly to protect nontraditional signifiers, such as color sans design or slogan, provided other doctrines of trademark law are satisfied.

This Comment suggests that the Lanham Act does protect color marks, but that courts should end their abstract approach to the question of whether color alone may be protected. "Mere color" should be treated in a manner similar to traditional verbal signifiers. As with traditional signifiers, courts should apply the widely accepted classification system suggested by Judge Friendly in Abercrombie \& Fitch Co. $v$ Hunting World, Inc. ${ }^{11}$ to determine whether a given color is distinctive enough to serve as a trademark. In addition, courts should recognize that not all colors are created equal. Courts should examine several factors, including aspects of how the color and the product appear in the relevant market; technical considerations, both in creating a particular color and in applying the color to the product; and the physiological, psychological, and cultural aspects of a color.

Section I introduces the Lanham Act and basic trademark doctrines, and Section II describes the widely varying views of federal appellate courts on the question of whether color warrants trademark protection. Section III explores the physics, physiology, and psychology of color, and discusses how protecting "mere color" trademarks may produce efficiency gains in the form of reduced consumer search costs. Section IV presents additional efficiency rationales for granting Lanham Act protection to "mere color." Finally, Section V discusses how courts may apply the Abercrombie \& Fitch distinctiveness hierarchy to determine which "mere color" marks should receive protection.

8 Id at 1027-28.

9 See Master Distributors, Inc. $v$ Pako Corp., 986 F2d 219 (8th Cir 1993) (rejecting a per se rule against allowing a manufacturer to trademark the blue color of its "Blue Max" splicing tape).

${ }_{10}$ See In re Owens-Corning Fiberglas Corp., 774 F2d 1116, 1128 (Fed Cir 1985) (allowing the registration of the color pink as a trademark for fibrous glass insulation).

11537 F2d 4, 9-11 (2d Cir 1976). Judge Friendly developed a test for determining the propriety of trademark protection for words. This test categorizes words as (1) generic, (2) descriptive, (3) suggestive, or (4) arbitrary or fanciful. Generic words are the least distinctive and hardest to protect; arbitrary or fanciful words are the most distinctive and easiest to "own." 


\section{THE LANHAM ACT}

The Lanham Act was designed to prevent unfair competition and to protect purchasers' expectations of quality. ${ }^{12}$ At its heart, the Act forbids one manufacturer from taking advantage of the good name of another. A manufacturer may register a mark to identify its goods in the marketplace and thus distinguish its goods from those of others. ${ }^{13}$ One also may register a mark to describe a service. ${ }^{14}$ To ensure the protection of trademarks, the Act imposes civil liability on a manufacturer who uses unregistered signs and symbols in a manner that would mislead purchasers as to the source, origin, or manufacturer of a product. ${ }^{15}$

The language of the Lanham Act places few restrictions on what may be registered as a trademark and does not expressly require that trademarks be verbal or even visual. ${ }^{16}$ Still, trademark law does impose some limits on what symbols are eligible for protection. The two primary limitations are the requirements of distinctiveness and nonfunctionality.

\section{A. Distinctiveness}

Courts distinguish among word trademarks based on how distinctive the words are; the more distinctive the word, the more it is entitled to protection. ${ }^{17}$ When evaluating the distinctiveness of a mark, courts generally refer to the framework set forth by Judge Friendly in Abercrombie \& Fitch. Under this system, a single mark, used by a single manufacturer, can be generic, descriptive, suggestive, or arbitrary. This characterization often depends on slight differences in the type of product to which the mark pertains. In Abercrombie \& Fitch itself, which involved a dispute between two clothing and sporting goods manufacturers, the court applied the hierarchical distinctiveness test and held that the mark "Safari" was generic with respect to trousers (part of a "Safari suit"), descriptive with respect to boots (designed to be worn while on safari), and suggestive with respect to

12 Two Pesos, Inc. $v$ Taco Cabana, Inc., 112 S Ct 2753, 2757 (1992) (noting the "Lanham Act was intended to 'make actionable the deceptive and misleading use of marks' and 'to protect persons engaged in ... commerce against unfair competition'"), quoting Inwood Labs., Inc. $v$ Ives Labs., Inc., 456 US 844, 858 (1982).

13 See 15 USC $\$ 1051$.

14 See 15 USC § 1053.

15 See 15 USC $\S 1125$.

16 See 15 USC \& 1052.

17 See Abercrombie \& Fitch, 537 F2d at 9. The Supreme Court has given its blessing to the Abercrombie \& Fitch system of classification. See Two Pesos, $112 \mathrm{~S} \mathrm{Ct}$ at 2760. 
swimsuits (designed to evoke a romantic association with an African hunting expedition-even though one rarely wears swim trunks while hunting elephants). ${ }^{18}$

Generic words are not considered distinctive; they are said to refer to the type of product, rather than to the manufacturer. ${ }^{19}$ "Rice," for example, can never be protected as a trademark for white rice because a manufacturer "cannot deprive competing manufacturers of the product of the right to call an article by its name."20 Furthermore, an originally distinctive mark may, over time, come to serve as the name of the product type. If a signifier becomes generic in this fashion, it loses its trademark protection. ${ }^{21}$

Descriptive marks describe an important aspect of the product, but not the product itself..$^{22}$ A descriptive mark is not presumptively distinctive, and without more it may not be protected as a trademark. ${ }^{23}$ The mark may acquire distinctiveness, however, if over time purchasers come to associate the mark with a particular source or manufacturer and distinguish between goods that possess the mark and those that do not. ${ }^{24}$ This acquired distinctiveness is referred to as the mark's secondary meaning. "Rice," for example, would be a descriptive word with respect to crackers made from rice ("cracker" would be a generic term and therefore unprotectable). "Rice" would be protectable only if purchasers knew that "Rice" brand rice crackers were made by a particular, single manufacturer, or if purchasers viewed "Rice" brand rice crackers as somehow different from other brands, thus giving "rice" a secondary meaning.

18537 F2d at 9-13.

Io Id at 9 .

20 Id.

21 See DuPont Cellophane Co. $v$ Waxed Products Co., 85 F2d 75 (2d Cir 1936) (“cellophanen lost trademark protection because the term became generic). On rare occasions, a manufacturer may reclaim an originally distinctive mark found to have become generic. For example, after Singer's sewing machine patent expired and the right to produce the machines had passed to the public, June Manufacturing Company used Singer's mark on its own machines with the intention of deceiving consumers. The Supreme Court held that June should be enjoined from using the Singer mark unless it clearly distinguished its product from Singer's. See Singer Mfg. Co. v June Mfg. Co., 163 US 169 (1896).

22 See Abercrombie \& Fitch, 537 F2d at 10.

23 See id. See also 15 USC \& 1052(e).

24 See Two Pesos, $112 \mathrm{~S} \mathrm{Ct}$ at 2757-60. Proof that the mark has become distinctive may be achieved by a showing of "substantially exclusive and continuous use ... by the applicant in commerce for the five years before the date on which the claim of distinctiveness is made." 15 USC \& 1052(f). 
"Suggestive" and "arbitrary or fanciful" words are considered distinctive marks and may therefore be protected under the Lanham Act even without a showing of secondary meaning. ${ }^{25} \mathrm{~A}$ suggestive word describes the product in a more abstract way than does a descriptive word and requires the purchaser to exert some mental effort to connect the word with the product. "Rice," then, would be a descriptive mark with respect to rice paper, but would be a suggestive mark with respect to kimonos.

Arbitrary and fanciful words are generally afforded full protection under the Lanham Act. ${ }^{26}$ An arbitrary word is a common word used in a strikingly unconventional manner. "Rice" would be an arbitrary term if used to identify a brand of bulldozer. A fanciful word is one invented solely to identify a brand. "Rixrix!" could be a fanciful trademark for rice.

\section{B. Functionality}

Although the Lanham Act does not expressly discuss nonfunctionality as a requirement for trademark protection, courts have held that a trademark may not be protected if it is an essential characteristic of what makes the product do what it does, or be what it is. ${ }^{27}$ A manufacturer cannot, for example, register a handle as a trademark for his brand of water pitcher. He could, however, register the distinctive shape of a handle as his trademark, so long as the distinctive shape does not increase the handle's functionality. ${ }^{28}$

Functional features may not be protected under trademark law, because doing so would defeat the patent law's goals of giving inventors only a limited monopoly over their inventions and refusing protection of inventions that are either obvious or insufficiently innovative. ${ }^{29}$ If functional features could be trademarked, then an inventor could perpetually prevent competitors from using such features on their products even after his patent expired. Additionally, a manufacturer could preclude the use of a particular feature even when the feature would never have been

${ }^{25}$ See Abercrombie \& Fitch, 537 F2d at 10-11; Two Pesos, 112 S Ct at 2759.

${ }_{26}$ See Abercrombie \& Fitch, 537 F2d at 10-11; Two Pesos, 112 S Ct at 2759.

27 The Restatement of Torts $\S 742$ (1938), describes a functional feature as one that affects the "purpose, action or performance [of a good], or the facility or economy of processing, handling or using" a good.

${ }_{28}$ See, for example, In re Morton-Norwich Products, Inc., 671 F2d 1332, 1341-43 (CCPA 1982) (spray-bottle design held nonfunctional).

${ }^{29}$ See J. Thomas McCarthy, 1 Trademarks and Unfair Competition § 7:26 at 236-37 (Law Co-op, 1984 \& Supp 1991). 
patentable in the first place. ${ }^{30}$ Any competitor may copy an unpatentable but useful feature: "Our natural inclination to disapprove of such conduct must give way to the public policy favoring competition, even by slavish copying. "31 To preclude competitors from imitating functional designs or features would deny them the opportunity to compete effectively. ${ }^{32}$

Two types of functionality limit the scope of trademark protection: utilitarian functionality and aesthetic functionality. Utilitarian functionality pertains to the efficiency of design, ease of use, ease of manufacture, cost of production, and similar aspects of the product's material utility or quality. ${ }^{33}$ A utilitarian functionality argument prevailed in Inwood Labs., Inc. $v$ Ives Labs., Inc., where the Supreme Court refused, on procedural grounds, to hold that the color of a prescription drug should be afforded Lanham Act protection. ${ }^{34}$ The Court refused to enjoin "generic" drug manufacturers from copying colors used by the "brand name" manufacturers. The Court let stand the district court's finding that color on prescription drugs is functional because patients mingle their medication and rely on color to distinguish one pill from another, because color may aid speedy identification in emergency situations, and because color may help eliminate the possibility of a pharmacist's confusing one dosage or medication with another. ${ }^{35}$

Aesthetic functionality is a much more ambiguous concept. It relates to design aspects that neither reduce the cost of manufacture nor make the product easier to use, but nevertheless contribute to the commercial success of the product. ${ }^{36} \mathrm{~A}$ heart-shaped

30 See Keene Corp. v Paraflex Industries, Inc., 653 F2d 822, 824 (3d Cir 1981); Sylvania Electric Products, Inc. v Dura Electric Lamp Co., 247 F2d 730, 732 (3d Cir 1957).

31 Keene Corp., 653 F2d at 824.

32 See Morton-Norwich, 671 F2d at 1339-40.

33 See McCarthy, 1 Trademarks and Unfair Competition $\$ 7: 26$ at 238-43 (cited in note 29).

${ }^{34} 456$ US 844 (1982).

${ }^{36}$ Id at 853 . See also Justice White's concurring opinion, which would have reached the merits of the dispute. Id at 859, 862-63. Commentators have spilled much ink in discussing the Lanham Act's application to the prescription drug industry. See, for example, Note, Issues in the Federal Registration of Flavors as Trademarks for Pharmaceutical Products, 1993 U III L Rev 105 (1993); Joseph P. Bauer, A Federal Law of Unfair Competition: What Should Be the Reach of Section 43(a)?, 31 UCLA L Rev 671 (1984); Steven M. Weinberg, Drug Capsule Color Copying in the Wake of Ives: A Comment on Two Decisions, 72 Trademark Rptr 285 (1982); Iver P. Cooper, Trademark Aspects of Pharmaceutical Product Design, 70 Trademark Rptr 1 (1980); Paul D. Parnass, Color and Appearance-A Trademark Issue, 21 Idea 192 (1980).

${ }^{36}$ See McCarthy, 1 Trademarks and Unfair Competition \$ 7:26 at 246 (cited in note 29). See also Schwinn Bicycle Co. $v$ Ross Bicycles, Inc., 870 F2d 1176, 1190 (7th Cir 1989) 
box for Valentine's Day candy, for example, could be seen as aesthetically functional; if one manufacturer could monopolize that shape, he would have a tremendous advantage over his competitors. For whatever reason, many consumers simply will not buy Valentine's Day candy unless it is in a heart-shaped box. ${ }^{37}$ A manufacturer of marbles, however, could trademark a heart-shaped box because few potential purchasers of marbles would refuse to buy marbles not packaged in a heart-shaped box. But the term "aesthetic" does not imply that a visually appealing design may never be protected as a trademark. The Third Circuit, for example, cautioned against overbroad application of the doctrine in Keene Corp. $v$ Paraflex Industries, Inc.:

[The doctrine of aesthetic functionality] provides a disincentive for development of imaginative and attractive design. The more appealing the design, the less protection it would receive. As our ambience becomes more mechanized and banal, it would be unfortunate were we to discourage use of a spark of originality which could transform an ordinary product into one of grace. The doctrine of aesthetic functionality need not be construed in such a manner for it to fulfill its important public policy function of protecting free competition. ${ }^{38}$

The Keene Corp. court, however, denied trademark protection to the design of a light fixture because "part of its function includes its architectural compatibility with the structure or building on which it is mounted. Thus, its design configuration, rather than serving merely as an arbitrary expression of aesthetics, is intricately related to its function."

Courts have expressly and implicitly relied on the aesthetic functionality doctrine when denying trademark protection to colors. ${ }^{40}$ The doctrine has not, however, gained universal accep-

(trial court erred in ignoring aesthetic features in functionality determination); Restatement of Torts $\S 742$, comment a (1938).

${ }^{37}$ See Restatement of Torts $\& 742$ comment a (1938).

38653 F2d at 825 .

${ }^{39}$ Id at 826.

40 See AmBrit, Inc. v Kraft, Inc., 812 F2d 1531, 1548-49 (11th Cir 1986) (implying reliance on an aesthetic-functionality rationale based on what feelings consumers associate with the color royal blue); First Brands Corp. $v$ Fred Meyer, Inc., 809 F2d 1378, 138183 (9th Cir 1987) (finding "a competitive need" for the color yellow in the retail antifreeze market and therefore ruling the color yellow functional); Deere \& Co. v Farmhand, Inc., 560 F Supp 85, 95-98 (S D Iowa 1982), aff'd, 721 F2d 1253 (8th Cir 1983) (per curiam) (finding a competitive need for the color green, since purchasers of farm equipment would 
tance, and was rejected by the Federal Circuit's predecessor, the Court of Customs and Patent Appeals. ${ }^{41}$

\section{The Purchaser Confusion Balancing Act}

A mark on a product relays a message to the purchaser. The central question in most trademark cases is whether the mark, through its message, tells the purchaser something useful and special, or conversely, gives him no additional information and perhaps deceives him. If the mark is not distinctive, it conveys no additional information about the source or quality of the goods. Additionally, purely functional aspects of a product say nothing to the purchaser; they merely make the product do what it is supposed to do. If I buy a Swiss Army knife because it comes with a can opener, my purchasing decision really is independent of any message the product's appearance sends to me. But if I buy a knife with a can opener because I see the Swiss Army cross on it, I have made my decision on the basis of the message the product sends to me. Indeed, my total economic costs of purchasing the knife are reduced because I do not need to open the knife in the store to learn of the enclosed can opener. If, however, when I get home, I open the knife and find no can opener inside, I have been cheated.

The manufacturer who misappropriates a trademark defrauds the purchaser by inducing him to rely on the reduced search costs promised by the mark. Indeed, trademark litigation often turns on the factual question of whether the defendant's use of a certain symbol poses a likelihood of confusing the typical purchaser: Does the defendant use a symbol in a manner that a

want all their equipment to match). But see Master Distributors, Inc. $v$ Pako Corp., 986 F2d 219, 221-22 (8th Cir 1993) (noting the limited extent of the Deere \& Co. holding); In re Deere \& Co., 7 USPQ2d (BNA) 1401, 1404 (TTAB 1988) (rejecting an aesthetic functionality argument and allowing Deere \& Co. to register a trademark for farm equipment where the equipment was green but with yellow wheels).

4 See Application of Mogen David Wine Corp., 328 F2d 925, 931 (CCPA 1964). The Fifth and Sixth Circuits also have rejected the doctrine. See Sicilia Di $R$. Biebow \& Co. $v$ Cox, 732 F2d 417, 428 (5th Cir 1984); WSM, Inc. v Tennessee Sales Co., 709 F2d 1084, 1087 (6th Cir 1983). The Second and Tenth Circuits have sharply limited the doctrine. See Wallace Int'l Silversmiths, Inc. v Godinger Silver Art Co., Inc., 916 F2d 76 (2d Cir 1990); Brunswick Corp. $v$ Spinit Reel Co., 832 F2d 513, 518-19 (10th Cir 1987). See also McCarthy, 1 Trademarks and Unfair Competition \$ 7:26 at 247 (cited in note 29) ("The notion of 'gesthetic functionality' is an unwarranted and illogical expansion of the functionality policy."). Significantly, in a recent case, the Ninth Circuit ordered the cancellation of a "mere color" trademark, but did not do so on functionality grounds and did not use the case as a vehicle for reaffirming the doctrine of aesthetic functionality. See Qualitex Co. $v$ Jacobson Products Co., 13 F3d 1297, 1304-05 (9th Cir 1994). 
reasonable purchaser would view as an implicit promise that this product comes from that source? ${ }^{42}$

Trademark law must protect those symbols that tell the purchaser something useful about the source of a product and must protect only those symbols. As the discussion of functionality indicated, protecting too much under the realm of trademark law disserves the public by discouraging beneficial competition.

\section{The SPLit OVER "Mere ColoR"}

Until 1985, it was well settled among the lower courts that no single color could ever be distinctive enough to be granted trademark protection. Color could be protected as a trademark only to the extent that it was used as part of a pattern of other colors, words, or symbols. ${ }^{43}$ Courts' reluctance to grant trademark protection to "mere color" was in part due to the "color depletion" rationale, which held that granting trademark protection to mere color would have anticompetitive effects because the first producers to enter the market could snap up all the good colors. ${ }^{44}$ Additionally, courts refused to protect patterns of just a few colors. ${ }^{45}$

The Federal Circuit broke sharply away from the "color depletion" orthodoxy in 1985 with its decision in In re Owens-Corning Fiberglas Corp. ${ }^{46}$ The court noted that Congress intended the Lanham Act to be read broadly to allow protection of a wide variety of trademarks: "The principal purpose of the Lanham Act

42 See Park 'N Fly v Dollar Park \& Fly, Inc., 469 US 189, 198 (1985) (Lanham Act protects "the ability of consumers to distinguish among competing products"). See also Pignons S.A. de Mecanique de Precision v Polaroid Corp., 657 F2d 482, 487 (1st Cir 1981) (noting the Lanham Act's primary purpose is to prevent purchaser confusion).

43 See, for example, Dallas Cowboys Cheerleaders, Inc. v Pussycat Cinema, Ltd., 604 F2d 200, 204 n 6 (2d Cir 1979), citing Quabaug Rubber Co. v Fabiano Shoe Co., 567 F2d 154,161 (1st Cir 1977) ("Although color alone is not capable of becoming a trademark, a combination of colors together with a distinctive arbitrary design may serve as a trademark.").

" See, for example, Campbell Soup Co. v Armour \& Co., 175 F2d 795, 798 (3d Cir 1949) ("If they may thus monopolize red in all of its shades the next manufacturer may monopolize orange in all its shades and the next yellow in the same way. Obviously, the list of colors will soon run out.... [M]an cannot acquire a trademark by color alone....".).

45 See Diamond Match Co. v Saginaw Match Co., 142 F 727, 729 (6th Cir 1906) (where it is important that the head and tip of a match be different colors to enable users to distinguish on which tip the match should be struck, manufacturers are not entitled to a monopoly of any two particular colors).

46774 F2d 1116 (Fed Cir 1985). 
was the modernization of trademark law, to facilitate commerce and to protect the consumer .... Under the Lanham Act trademark registration became available to many types of previously excluded indicia. Change was gradual and evolutionary," but eventually the Patent and Trademark Office permitted registration of such varied marks as sounds, candy-bar wrappers, slogans, ornamental labels, and "goods which take the form of the mark itself." ${ }^{\text {"77 }}$ The court described Owens-Corning's pink as "akin to an over-all surface design." ${ }^{48}$ The court also noted that the evidence Owens-Corning presented on the scope and effects of its advertising campaign clearly established a secondary meaning of the color pink because an extraordinarily large number of homeowners identified pink with Owens-Corning. ${ }^{49}$

Additionally, the court held that the color depletion theory should not be used in all circumstances to prohibit the trademarking of a single color under all circumstances. In determining whether to trademark a color, courts should consider "the nature of the goods, how the color is used, the number of colors or color combinations available, the number of competitors, and customary marketing practices. ${ }^{950}$

In dissent, Judge Bissell argued that the majority improperly ignored longstanding doctrine holding that color may not be protected as a trademark absent some other design feature. According to him, protecting "mere color" would also have anticompetitive effects, not because color depletion doctrine so demanded, but because Owens-Corning was so successful in its efforts to get purchasers to associate pink with its products. "[B]y reason of the dominance of Owens-Corning in the field ... pink insulation has become virtually synonymous with home insulation," and many consumers demand that their insulation be pink. ${ }^{51}$ To purchasers, "pink" represents insulation in the same way that "yellow" represents legal pads. Judge Bissell also argued that courts would face intractable problems in distinguishing one shade of color from another, a difficulty that would out-

47 Id at 1119-20 (citations omitted). See also S Rep No 1333, 79th Cong, 2d Sess (May 14, 1946), reprinted in 1946 US Code Cong Serv 1274 (noting some of the Lanham Act's purposes are "to simplify registration and to make it stronger and more liberal, [and] to dispense with mere technical prohibitions and arbitrary provisions").

4 Owens-Corning, 774 F2d at 1123.

4 Id at 1126-28.

so Id at 1120 .

s1 Id at 1130 (Bissell dissenting). This analysis comes very close to finding that pink is aesthetically functional. See text accompanying notes 36-41. 
weigh any possible benefit of allowing color trademark protection. Even if protecting color would reduce purchaser confusion slight$\mathrm{ly}$, the administrative costs of determining when a color is in fact confusing would be too great. ${ }^{52}$

In NutraSweet Co. $v$ Stadt Corp., the Seventh Circuit expressly rejected the Federal Circuit's reasoning and affirmed traditional doctrine barring "mere color" trademarks. ${ }^{53}$ NutraSweet used a shade of pastel blue on the packaging for the artificial sweetener it sold to restaurants and sought an injunction barring its competitors from using a different but "confusingly similar" shade of blue. The Seventh Circuit criticized the Federal Circuit for ignoring longstanding doctrine and warned that the Federal Circuit's approach would inevitably lead to extended and wasteful litigation over the degree to which one shade could be distinguished from another. The court, noting that the colors at issue were in fact distinguishable, refused to descend into the quagmire of determining how distinguishable was distinguishable enough to ensure that purchasers would not be confused. The court also criticized the Federal Circuit's concern for the number of competitors in the market, contending that no court could predict how many competitors would enter the market in the future, or even if any would enter at all. ${ }^{54}$

The Courts of Appeals remain divided on the question of color trademarks. The Eighth Circuit adopted the Federal Circuit's liberal approach, noting the large variety of distinguishable shades of colors and pooh-poohing the Seventh Circuit's concern for shade confusion: "Triers of fact must often answer close and difficult questions, and the traditional likelihood of confusion standard should be applied to distinguish similar colors, as it is when similar slogans, symbols, numbers, or words are compared." ${ }^{15}$ The Ninth Circuit, after dithering in First Brands Corp. $v$ Fred Meyer, Inc. ${ }^{56}$ and International Jensen, Inc. $v$ Metrosound U.S.A., Inc. ${ }^{57}$ finally reaffirmed the "mere col-

52 Id at 1131.

63 917 F2d 1024 (7th Cir 1990).

54 Id at 1026-28.

s5 Master Distributors, Inc. v Pako Corp., 986 F2d 219, 223 (8th Cir 1993) (citations omitted).

s5 809 F2d 1378, 1382 (9th Cir 1987) (recognizing the continued vitality of the color depletion theory).

${ }^{57} 4$ F3d 819, 823-24 (9th Cir 1993) (questioning the continued vitality of color depletion theory). 
or" rule in Qualitex Co. $v$ Jacobson Prods. Co. ${ }^{58}$ Academic opinion is also divided on this issue. ${ }^{59}$

Although the Supreme Court has made no attempt to address the issue, the Court's broad understanding of the reach of Lanham Act protection seems to favor the Federal Circuit's approach. In Two Pesos, Inc. $v$ Taco Cabana, Inc., the Court noted the broad scope of the Lanham Act and held that inherently distinctive trade dress could be protected even without a showing of secondary meaning. ${ }^{60}$ Trade dress is how a product appears in the marketplace to potential purchasers. ${ }^{61}$ Examples of trade dress include a restaurant's interior design, ${ }^{62}$ a candy wrapper $^{63}$ and the shape of a wine bottle. ${ }^{64}$

Most color trademark cases can best be described as trade dress cases because the manufacturer is most concerned with securing protection for her product's color as it appears in the marketplace-where it is typically in combination with other marketing elements. One could, however, visualize a non-trade dress color trademark case. A commercial computer bulletin board, for example, could develop a marketing campaign based on a slogan such as: "Sick of Big Blue? Tap into the Big Purple network." The company could follow up on its initial campaign by hiring skywriters to release clouds of purple smoke over football stadiums, or purchasing five-second television advertising slots and broadcasting nothing but purple, or erecting big purple billboards, without any text or graphics on them. Purple in this situation would be a non-trade dress, color service mark. Although such a case would not fit well under traditional trade dress doctrine, the Supreme Court has emphatically stated that the text of the Lanham Act suggests no basis for treating verbal,

B8 13 F3d 1297, 1302 (9th Cir 1994).

69 For support of the "mere color" rule, see McCarthy, 1 Trademarks and Unfair Competition \& 7:16 at 42-43 (cited in note 29). For opposition to the rule, see Andrew W. Coleman, Color as Trademarks: Breaking Down Barriers of the Mere Color Rule, $74 \mathrm{~J}$ Patent \& Trademark Office Society 345 (1992); Brian Richard Henry, Right Hat, Wrong Peg: In Re Owens-Corning Fiberglas Corp. and the Demise of the Mere Color Rule, 76 Trademark Rptr 389 (1986); Charles H. Ellerbrock, Trademark Registration of a Color Having Secondary Meaning: In Re Owens-Corning Fiberglas Corporation, 27 Idea 7 (1986). The business community wants this issue settled one way or the other, and soon. See Junda Woo, Rulings Clash Over Colors in Trademarks, Wall Street J B1 (Feb 25, 1993).

112 S Ct 2753, 2758-61 (1992).

61 See id at $2755 \mathrm{n} 1$.

62 Id at 2755-56.

63 In re World's Finest Chocolate, Inc., 474 F2d 1012 (CCPA 1973).

a Application of Mogen David Wine Corp., 328 F2d 925 (CCPA 1964). 
symbolic, and trade dress trademarks under different standards. ${ }^{65}$

\section{Color, THE MARKETPLACE, AND THE LAW}

Economists offer a different approach to color trademarks, and their analysis provides necessary support where judicial rationales are weak. An economist would argue that the law should recognize and protect color trademarks when the supply of colors appropriate for a given product is large, because under these circumstances purchaser search costs would be reduced with little efficiency loss resulting from heightened barriers to entry. ${ }^{66}$ This Section discusses how courts may apply this principle to real-life situations. An examination of some of the science, physiology, and psychology behind human perception of color indicates that the NutraSweet court's concerns about the distinguishability of colors can in many cases be resolved at low cost. The benefits gained from reducing purchaser confusion can often outweigh the difficulties courts may face when determining if such confusion does in fact exist.

\section{A. Physics and Physiology}

Nearly all judicial discussion of the "mere color" rule ignores the physical and psychological realities of color. Proponents of the color depletion theory argue that granting trademark protection to a particular color would have anticompetitive effects because potential competitors would be denied access to a limited stock of attractive colors. ${ }^{67}$ Courts are particularly afraid of limiting access to the "primary colors." Fi Furthermore, those courts opposed to Lanham Act protection of "mere color" cite the difficulty of

${ }_{65}$ Two Pesos, $112 \mathrm{~S} \mathrm{Ct}$ at 2760 . See also Justice Thomas's concurring opinion, $112 \mathrm{~S}$ $\mathrm{Ct}$ at 2766-67 ("Over time, judges have come to conclude that packages or images may be as arbitrary, fanciful, or suggestive as words or symbols, their numbers limited only by the human imagination.").

${ }_{68}$ See William M. Landes and Richard A. Posner, Trademark Law:An Economic Perspective, 30 J L \& Econ 265, 288-89, 297-99 (1987).

${ }_{67}$ See, for example, NutraSweet, 917 F2d at 1028.

63 See, for example, First Brands Corp., 809 F2d at 1382 n 3 (finding that the district court clearly based its refusal to protect the yellow color of an antifreeze container on the color depletion theory and on the notion that yellow is a primary color); Campbell Soup Co. $v$ Armour \& Co., 175 F2d 795, 798 (3d Cir 1949), quoting Pacific Coast Condensed Milk Co. v Frey \& Co., 85 Wash 133, 147 P 865, 869 (1915) (noting that there are few primary colors); Diamond Match Co. v Saginaw Match Co., 142 F 727, 729 (6th Cir 1906) (same). 
distinguishing one shade of color from another. ${ }^{69}$ At the same time, however, proponents of the color depletion theory do not even discuss the nature of color and of primary color, and what distinguishes one color from another. An investigation into the properties of color reveals that the color depletion theory has little scientific basis.

Without a scientific understanding of color, courts will find it difficult to develop a color trademark jurisprudence that will adequately protect both businesses and consumers. Although light may be described in terms of the wavelength of electromagnetic energy, and although perceived color corresponds to light's wavelength, color truly exists only in the human mind. ${ }^{70}$ What the mind perceives as color depends on the amount of stimulation received by receptors in the eye. These receptors are called cones, and normal humans have three kinds of cones: $R, G$, and $B$. $R$ cones are most stimulated by electromagnetic energy corresponding to the red part of the spectrum, $G$ by the green part, and $B$ by the blue part. ${ }^{71}$

A color is composed of three elements: hue, saturation, and value. What the mind perceives as hue depends on the relative degree of stimulation of the eye's receptors. ${ }^{72}$ Hue is what people normally think of when they think of color. Different hues are represented on an artist's color wheel. Red and green, for example, are different hues. Red and pink, however, are different variants of the same hue, red. Saturation, or chroma, is the degree of a color's intensity. High saturation colors look bold, while colors with low saturation look greyish and washed out. ${ }^{73}$ Value is the degree of a color's lightness or darkness; the higher the value, the lighter the color appears. ${ }^{74}$ These three characteristics of color are independent of each other. Royal blue, for example, could describe a range of the hue "blue" with a relatively high

69 Nutrasweet, 917 F2d at 1027; Qualitex, 13 F3d at 1302.

70 See Robert M. Boynton, Human Color Vision 45-50 (Holt, Rinehart and Winston, 1979). For example, not every wavelength of electromagnetic radiation corresponds to a given color. In addition, sometimes physically different blends of light produce identical sensations of color in a human observer. Id at 50.

71 Id at 122. The eye also contains light receptors called rods, which are very sensitive to light and dark. Rods are not as important for perception as are cones, but are extremely important for night vision. Id at 113-15.

72 Id at 113.

73 Id at 30.

74 See Kenneth L. Kelly and Deane B. Judd, Color: Universal Language and Dictionary of Names A-1 (US GPO, 1976). 
saturation but a relatively low value. ${ }^{75}$ Sky blue could describe a blue of the same hue, but with a lower saturation and higher value. ${ }^{76}$

The human eye can distinguish between minute differences of hue, value, or saturation. The National Bureau of Standards notes that although there are approximately three hundred verbal designations of color, under good lighting conditions the average person can distinguish among five million shades. ${ }^{77}$ One verbal color term, then, such as "royal blue," can refer to nearly twenty thousand distinguishable colors. ${ }^{78}$

\section{B. Should the Law Treat "Primary Colors" Differently?}

The color depletion theory does not justify a flat ban on trademarking "primary colors." First, cases discussing the special position of "primary colors" never specify exactly what a primary color is and fail to distinguish between "light primaries" and "pigment primaries." Second, even if the primary hues were assigned a special legal role, courts could nonetheless allow manufacturers to trademark narrowly defined ranges of particular primary hues.

The primary hues of light (the three colors of light that when added together produce white light) are precise shades of orangered, violet-blue, and green. ${ }^{79}$ The primary pigment hues (the three precise shades that when present in equal quantities absorb all visible light, and therefore are said to sum to black) are magenta red, green-blue, and yellow. ${ }^{80}$ When a court says that primary colors are special in some general way, that these particular shades are somehow more common or more recognizable, it is not saying much at all, and certainly is not saying enough to formulate a proper legal rule. ${ }^{81}$ Courts have been loose in their definition of "primary color." Various shades of red, yellow, and blue have been described as primary colors, with absolutely zero

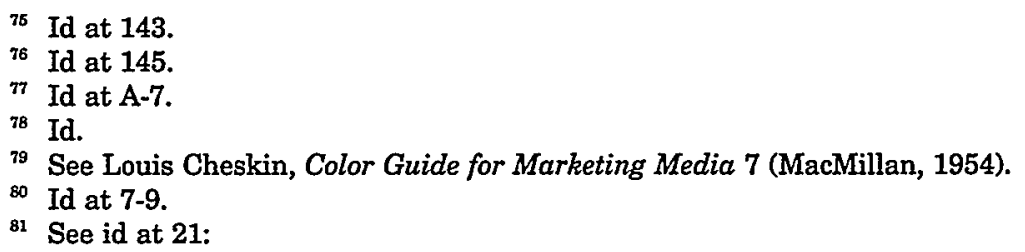

It is now clear that the true blue and the commonly recognized red are not primaries, either in light or in pigment. On the color chart or on a color wheel blue lies between green-blue (a pigment primary) and violet-blue (a light primary). Red lies between magenta red (a pigment primary) and orange-red (a light primary). 
discussion of whether the particular shades in question were in fact true primaries from a scientific standpoint. ${ }^{82}$

Second, even if the courts accorded the primary hues, properly defined, special legal significance, a better legal rule would be to allow a manufacturer to trademark a particular hue within a certain well-defined and narrow range of value and saturation. At trial, the finder of fact could determine whether two colors are so close as to create a likelihood of confusion. For registered marks, the registrant could submit a sample of the color, along with a description. If "a high impact, fresh floral fragrance reminiscent of Plumeria blossoms" describes a scent with sufficient particularity, ${ }^{83}$ then surely "a warm, brilliant sky blue reminiscent of a summer day in the English countryside" adequately describes a color. Other manufacturers would then still be free to use the same primary hue at other value and saturation levels. They could, for example, use "a subtle but majestic blue, reminiscent of the sky half an hour before a summer thunderstorm," which probably would have the same saturation level but a lower value. Alternatively, they could use "an icy blue, reminiscent of a perfect day for skiing," which perhaps would have a higher value but lower saturation. Granting protection in the form of allowing registration of the color therefore does not necessarily appreciably reduce the number of colors available to competitors, even if primary hues-however defined-are particularly popular.

Protecting an unregistered color through an infringement suit would have even fewer anticompetitive effects than would registering a color, because such a suit will determine only the narrow question of whether the defendant's use of color is confusingly similar to that of the plaintiff's, taking into account all pertinent aspects of the relevant market. In such a case the court need not worry about preventing all potential competitors, present and future, from using a particular color, but instead the court must only determine if one particular defendant is marketing his goods in a way that misleads purchasers. ${ }^{84}$

${ }_{82}$ See Campbell Soup Co. v Armour \& Co., 175 F2d 795, 798 (3d Cir 1949) (red); First Brands Corp., 809 F2d at 1382 n 3 (yellow); Diamond Match Co. v Saginaw Match Co., 142 F 727, 729-30 (6th Cir 1906) (red and blue).

${ }^{83}$ In re Clarke, 17 USPQ2d (BNA) at 1238. The registrant in Clarke was not required to submit a sample of the scent. Id at $1240 \mathrm{n} 6$ ("The era of scratch \& sniff has not reached the Patent and Trademark Office.").

84 Perhaps these competing concerns explain the anomalous result in Qualitex, 13 F3d at 1304-05, in which the Ninth Circuit upheld the plaintiff's award of damages on the grounds that the defendant intentionally copied the color of plaintiff's product, but the court at the same time cited the "mere color" rule and ordered cancellation of the 


\section{The Technical Feasibility of Producing Diverse Shades}

The fear that the range of available colors will be depleted, then, is an improper basis for refusing to grant Lanham Act protection to mere color marks. In some circumstances, however, the color depletion theory may serve as a useful test for determining whether a particular color mark should receive protection.

In considering a color trademark, ${ }^{85}$ courts should hear testimony about the effective range of colors technically available for a product. Even if a word trademark is easier to apply to a product than is a distinctive color, the party seeking protection of the color should nonetheless be allowed to show that it would be technically and economically feasible for a competitor to put a distinguishable color on a competing product. ${ }^{86}$

Consider sound marks as an analogy. A television broadcaster, for example, could choose any arbitrary arrangement of sounds to serve as a service mark. ${ }^{87}$ Similarly, a manufacturer could build a sports-car engine that hummed in a distinctive way. ${ }^{88}$ If automobile production technologies significantly limited the number of possible ways a sports-car engine could hum, the hum should not receive protection under the Lanham Act, since

plaintiff's registration of the color as a trademark. The court may have wished to protect this particular plaintiff from a competitor's unfair business practices while fearing future anticompetitive effects. Viewed this way, the Ninth Circuit seems to be practicing a form of acoustic separation. The Ninth Circuit's apparent rule of law is, "You can't trademark a color, but if your competitor copies your distinctive color in a manner that will mislead unsophisticated purchasers, he will be liable to you in damages for trade-dress infringement." But such semantic games simply allow courts to shirk their duty to provide clear rules by which businesspeople may order their affairs. See Meir Dan-Cohen, Decision Rules and Conduct Rules: On Acoustic Separation in Criminal Law, 97 Harv L Rev 625 (1984).

85 The concept of a color service mark might seem odd at first, but it should not. In fact, a striking, unusual color-divorced from any shape, form, or language-might be the perfect mark for a new, unusual, innovative service. See Jean-Paul Favre and André November, Color and und et Communication 26 (ABC Verlag, 1979).

${ }_{88}$ See Owens-Corning, 774 F2d at 1121 (court considered feasibility of using other colors in deciding whether use of color pink for fibrous insulation was functional). See also DAP Products, Inc. $v$ Color Tile Mfg., Inc., 821 F Supp 488, 495 (S D Ohio 1993) (magistrate's opinion) ("[I]n light of available contemporary technology[, t]here are a myriad of colors and shades available for products today that were certainly not available in the past.").

B7 See note 4.

${ }^{88}$ Car manufacturers do seek to install distinct engine sounds in their cars. For example, the chief engineer for the Mazda Miata noted: "We were working on the exhaust sound even before we had engines in test cars .... We believed that the right sound was very important." See Rich Ceppos, His Task Was Exhausting: Praise for Mazda Miata Automobile, Car \& Driver 23 (Apr 1990). 
allowing trademark protection would limit other manufacturers' ability to enter the market for sports-car engines. If, however, engines can hum in all sorts of ways, then an unusual hum should receive protection as a trademark, since it can identify the brand and distinguish it from competing brands. A purchaser, hearing the hum, can identify the engine's source without having to lift the hood of the car and inspect. Allowing other manufacturers to copy that hum would create the possibility of purchaser confusion.

Some items are tough to color, and certain colors are tough to mix because certain pigments are chemically incompatible. ${ }^{89}$ Many colors do not remain true; a manufacturer might find it difficult to produce a precise shade time and time again, and therefore might seek to protect a broader range of color. ${ }^{90}$ If, however, technology allows replication of precise shades on a given product, courts should be more willing to protect a color as a trademark because the manufacturer is depleting less of the available spectrum.

Similarly, if the constraints of mass production make it difficult for a manufacturer to ensure consistent color on all his products, courts should be less apt to allow the color to be protected because doing so would "deplete" more of the universe of color. But if the court determines that technological advances allow alternative colors to remain open to potential competitors, the court should allow protection to the broader range of color. Again, this relates to the purchaser confusion question; if purchasers identify a range of color with a particular source of a product, then the broader range-and not merely the specific shade-should be protected if doing so will not significantly hamper competition.

\section{Aspects of the Target Market}

Courts should also hear evidence on how the color appears in the marketplace, and if it is feasible-not technically feasible, but practically feasible, given the market's characteristics-for a competitor to put a distinguishable color on his product. A liquor manufacturer, for example, should probably not be permitted to register a "mere color" trademark or maintain a suit for infringement if the product is generally sold in smoky, dimly lit bars to

80 See Cheskin, Color Guide for Marketing Media at 11-12 (cited in note 79).

so Id at 12-13 (" $[\mathrm{A}]$ color, like love, may be either permanent or fugitive."). 
customers whose sensory faculties are dulled: the range of "available" colors is smaller and the possibility of depletion is greater. By contrast, a sporting goods manufacturer who primarily sells his products in broad daylight at portable beachfront stands should be allowed to protect a "mere color" trademark, because here the depletion concern is minimal. Again, the finder of fact could determine, based on the environment in which the product was sold, whether a reasonable purchaser is likely to confuse the two goods.

Demographic characteristics of the target market could also be important in determining what the available range of color is and therefore whether a particular color should be protectable. For example, since older people tend to lose some ability to distinguish one color from another, courts should be less willing to protect a color mark with respect to, say, prune juice or a similar product consumed chiefly by older people. ${ }^{91}$ Additionally, this diminution in ability to perceive certain colors might result in more colors being judged functional-and thus less protectable-in products marketed to elderly consumers.

Still, courts should keep in mind that purchasers may recognize and respond to extremely fine differences in hue, value, or saturation. The human eye is far more sensitive than most scientific instruments are to shade differences. ${ }^{22}$ For example, "[e]xperienced painters will not permit a batch of paint to run out in the middle of a wall, even if it is a standard commercial mix, because the eye will probably see a difference between the two areas, even though the label on the replacement can reads identically to that of the original."

Of course, if the purchaser never gets the chance to make a side-by-side comparison, she is more likely to be fooled by an infringer's similar shade. This point, however, does not establish that shade confusion necessarily supports barring color trademarks; instead it suggests that courts should examine the totality of the marketing circumstances when determining if the Lanham Act should permit registration of a "mere color" mark or whether a plaintiff shall be allowed to maintain an action for infringement of such a mark.

91 For a discussion of how aging affects color perception, see Boynton, Human Color Vision, at $369-71$ (cited in note 70 ).

92 Id at 253.

93 Id at 251. 
E. Psychological or Physiological Functionality

Colors have certain psychological and physiological properties that courts should consider when addressing the functionality question..$^{94}$ On surf boards, for example, bright colors would aid the rescue of a surfer who fell off because bright colors are-for physiological reasons-more likely to catch the eye of a potential rescuer. Indeed, physiological factors sometimes do explain a finding of utilitarian functionality. In Edward Weck, Inc. $v$ IM, Inc., for example, the court found that, in a hospital setting, the color green is functional because it prevents surgeons from seeing unsettling afterimages of recently completed surgery. ${ }^{95}$

Psychological rationales can also justify a finding of functionality. This is especially the case with food products. For example, on a can of grapefruit juice certain hues might accentuate aspects of the juice's taste better than others would. Indeed, given the importance of color to the marketing of food items, a court should be less likely to protect color as a trademark in cases involving food. This point might explain why the NutraSweet court refused to extend trademark protection to colors. Probably not even the Federal Circuit would allow Owens-Corning pink to be registered as a trademark for cotton candy. With food, the line between utilitarian and aesthetic functionality blurs:

Color plays a substantial, if not ultimate, role in our judgment of the freshness, ripeness, and palatability of food.

Appetite depends on the sense of sight just as much as on smell. Experiments have been done with people's appetites being stimulated by dishes containing the finest of delicacies shown under normal light. The substitution of

भ whe phenomenon of synaesthesias plays an important role in marketing. Synaesthesias take place whenever exposure to colors produces more than one stimulation ... when not only the sense of vision is concerned but other senses as well." Favre and November, Color and und et Communication at 26 (cited in note 85). See also Frank H. Mahnke and Rudolf H. Mahnke, Color and Light in Man-made Environments 107-14 (Van Nostrand Reinhold, 1987), for a discussion of synaesthetic effects in industrial settings.

so 17 USPQ2d (BNA) 1142, 1143-45 (TTAB 1990). See also American Hospital Supply Corp. $v$ Fisher Scientific Co., 1988 US Dist LEXIS 11000, *32 (N D Ill) (color orange held to be functional on medical waste bags); Russell Harrington Cutlery, Inc. v Zivi Hercules, Inc., 25 USPQ2d (BNA) 1965, 1968 (D Mass 1992) (white held to be functional on knife handles because it is easier to see whether a white handle has been cleaned properly than whether a colored handle has been). 
colored light produced nausea. Dark-gray meat, orchid potatoes, muddy-violet salads, black peas, and blue bread found no takers-even though the people knew the food was edible. ${ }^{96}$

Using similar reasoning, the Second Circuit held in part because Pepto-Bismol's use of the color pink serves to help soothe consumers' ailing stomachs, the color cannot be protected as a trademark. ${ }^{97}$ Pepto-Bismol pink does not merely help the purchaser identify what he wishes to consume (as does Owens-Corning fiberglas pink), but also is part of what the consumer consumes; he doesn't just drink the medicine, he drinks the pink. ${ }^{98}$

Just because the range of colors available to a product is limited, a court should not necessarily decline to grant the color trademark status. In the surf board example, even if the color of the product must have high value and saturation, a wide range of hues still may be available. Similarly, as in the grapefruit juice example, if the range of available hues is restricted, value and saturation may be permitted to vary greatly as long as such variation does not make the juice less palatable. Although a finding of functionality implies that all acceptable colors must have certain characteristics, such a finding does not necessarily imply that only one or a few colors are functional. In the Pepto-Bismol case, the consumer might not need to drink pink; any soothing color might do the trick. Functionality, like much else in the law, is a matter of degree.

\section{ADDitional EFficiency Rationales FoR PROTECTING DISTINCTIVE COLORS}

Assuming that one of the goals of trademark law is to maximize social wealth, any proposed rule should be justifiable on efficiency grounds. This Section will discuss efficiency gains that will likely result from the abolition of the "mere color" rule, over

${ }_{96}$ Mahnke and Mahnke, Color and Light in Man-Made Environments, 101-02 (cited in note 94). Note, however, that people's ideas of what colors are palatable change over time; blue cornbread, for example, is becoming increasingly popular in Southwestern-style restaurants.

${ }_{97}$ Norwich Pharmacal Co. v Sterling Drug, Inc., 271 F2d 569, 572 (2d Cir 1959). But see McCarthy, 1 Trademarks and Unfair Competition $\S 7: 21$ at 225 (cited in note 29) ("How does anyone know exactly what reaction the color pink produces in people with upset stomachs? It may make them feel worse, depending upon their subjective reactions to various colors-which varies widely among different people.").

98 Norwich Pharmacal, 271 F2d at 572. 
and above any gains resulting from reduction of purchaser search costs.

\section{A. Creation of New and Useful Signifiers}

Judge Posner and Professor Landes have suggested that trademark law benefits society by encouraging the development of language. ${ }^{99}$ Because manufacturers benefit from developing new and unusual words to describe their products, they have an incentive to develop such words. Consumers use the words to save time and energy when describing the product, and eventually the most useful words enter the language as generic terms, ultimately losing their trademark protection and becoming part of the public domain. Modern language is the richer for having words like yo-yo, trampoline, brassiere, aspirin, escalator, and jujubes. ${ }^{100}$

Extending trademark protection to colors would undoubtedly have the same advantages. Manufacturers would create new and more striking colors-or at least apply rarely seen colors-in more (and more unusual) contexts. Many of these colors would eventually lose their association with a particular product and enter the aesthetic language as generic, universally recognized signifiers. It could be argued that in the United States "Sanka orange" has become a generic color signifying "decaffeinated coffee." 101

Another reason to protect color is that it is more difficult to create and to apply color to a product than it is to create and apply a word. ${ }^{102}$ This additional cost of application, coupled with the public good aspects of colorful surroundings, may justify legal protection of distinctive use of color. Of course, those who think advertising is more often gaudy and ugly might disagree. On this view, colorful advertising is an externality, something the law should discourage. This issue boils down to a question of taste. We may safely assume, however, that those who wrote the Lanham Act opposed neither commerce nor advertising.

29 Landes and Posner, $30 \mathrm{~J} \mathrm{~L} \&$ Econ at 271-73 (cited in note 66).

100 McCarthy, 1 Trademarks and Unfair Competition $\S 12: 3$ at 533-38 (cited in note 29).

101 See text accompanying notes 122-30.

102 See DAP Products, Inc. $v$ Color Tile Mfg., Inc., 821 F Supp 488, 494 (S D Ohio 1993) (noting that both the plaintiff and defendant incurred additional costs to obtain red buckets, while both white and black were cheaper). 


\section{B. Color's Surprising Similarity to Other Signifiers}

Color marks (and other nonverbal signifiers) are more similar to word trademarks than may appear upon first examination. Those who create "new" word trademarks do so by choosing from the existing set of letters. In a very real sense they create nothing, but merely put existing signs into a previously untried arrangement. ${ }^{103}$ In a similar way, manufacturers may adjust hue, saturation, and value to create equally new and imaginative colors.

It may be easier to imagine word creation than to imagine color creation, but previously unknown colors have, in fact, been invented by artists. ${ }^{104}$ One example is International Klein Blue, a "brilliant, electric ultramarine" created in 1957 by the French artist Yves Klein. ${ }^{105}$ One critic described the color as having a unique "vividness, richness and sensuousness. Once seen it's never forgotten." 106

Once a color is used distinctively, it enters the visual language. Color can often be a more effective communication tool than words. ${ }^{107}$ When a manufacturer uses a distinctive color, he

103 In addition, because courts protect single-letter trademarks, the creator sometimes does not even need to arrange anything. "There is nothing, moreover, in decisional law to preclude a single letter from functioning as a trademark and, in fact, from serving as an arbitrary and strong mark." Michelin Tire Corp. v General Tire \& Rubber Co., 202 USPQ (BNA) 294, 298 (TTAB 1979) (protecting the letter ' $\mathrm{X}$ "); Singer Mfg. Co. $v$ Singer Upholstering \& Sewing Co., 130 F Supp 205, 208 (W D Pa 1955) (protecting the letter "S"). Numbers also may be registered as trademarks. Xerox Corporation, for example, holds a trademark on the number " 4024 " with respect to "nonsensitized electrophotographic copy paper." Trademark Registration No 917,675 (Aug 3, 1971). Oddly, no one has ever advanced a "letter depletion" theory that would support a blanket rule withholding trademark protection from all such marks. If a manufacturer may appropriate one letter out of a mere twenty-six, then surely he may appropriate one color out of several hundred-or several million, depending on how one counts the number of available colors.

104 That such an invented color could be protected by a design patent, under 35 USC $\S \S 171-73$ (1990), does not preclude its being protected under the Lanham Act. See Owens. Corning Fiberglas, 774 F2d at 1119-20; Application of Mogen David Wine Corp., 328 F2d 925, 929-31 (CCPA 1964). Does an artist who uses a color never before seen create it or merely discover it? The answer to this question, although perhaps of profound philosophical importance, is irrelevant to the legal analysis. In either case the color was once unavailable, but through human endeavor now is. It does not matter whether we view the artist as Zeus, who created fire, or Prometheus, who brought it to Earth.

${ }^{105}$ See Grace Glueck, Yves Klein Show at the Guggenheim, NY Times C26 (Nov 19, 1982).

${ }_{106}$ James Delingpole, Critic's Choice, Daily Telegraph 20 (Sept 4, 1993), quoting Julia Payton-Jones.

${ }^{107}$ One drawback is that the communication is generally unidirectional. The seller may choose either verbal or nonverbal signifiers. The consumer normally may not. He must say, "Sanka, please," in response to the question "What type of coffee?" But then, the consumer could just point to the orange pot. 
makes it easier for purchasers to seek out his products. This reduction in purchaser search costs is an efficiency gain justifying legal protection of the color mark. ${ }^{108}$ Additionally, the social gain simply from creating a previously unknown color may also be extremely valuable. ${ }^{109}$

\section{The Unsophisticated Purchaser}

Courts should be most willing to protect nonverbal trademarks when the verbal language fails to provide purchasers with the tools necessary to distinguish one manufacturer's product from that of another, and when purchasers are unsophisticated, unable to describe what they are looking for without reference to color. In these situations the distinctive use of color can have maximum communicative impact and therefore is most deserving of trademark protection.

Language is less powerful than lawyers believe. Word trademarks are sometimes less effective than nonverbal marks at identifying the source of goods. Sixteen to twenty-seven million adult Americans are functionally illiterate, able to read little more than a street sign. Forty-five million cannot read a newspaper. Perhaps as many as eighty-two million cannot understand Time magazine or compose a letter. ${ }^{110}$ Many Americans might be better able to judge whether two nonverbal signifiers are confusingly similar than to judge whether two verbal signifiers are confusingly similar.

Caselaw tends to support the proposition that color should be protected when other signifiers fail. In Master Distributors, Inc. $v$ Pako Corp., the court allowed Lanham Act protection for blue splicing tape, noting that purchasers frequently would not ask for this tape by its true name but instead "by asking for "the blue tape' or simply for 'blue."'111

208 See Landes and Posner, $30 \mathrm{~J} \mathrm{~L} \&$ Econ at 275-80 (cited in note 66), for a formal analysis of the role of trademark law in reducing consumer search costs.

${ }^{100}$ For example, an original Yves Klein blue painting sold in 1990 for nearly $£ 800,000$. Joseph Williams, Creative Accountancy, The Times (London) 19 (Oct 23, 1990).

${ }_{110}$ Edward E. Gordon, Judith A. Ponticell, and Ronald R. Morgan, Closing the Literacy Gap in American Business 23 (Quorum, 1991). Protecting nonverbal signifiers will make it less costly to be illiterate, thereby making the illiterate better off. There is, of course, a moral hazard problem here: making illiteracy less costly will reduce the incentive for a rational illiterate person to learn how to read.

111986 F2d 219, 220 (8th Cir 1993). 
Qualitex Co. $v$ Jacobson Prods. Co., illustrates this point even more clearly. ${ }^{112}$ In that case, the district court allowed a manufacturer of commercial dry-cleaning press pads to protect the color "brass \# 6587," described as a shade of greenish gold. The court in part based its holding on the fact that most drycleaning establishments are small family-owned businesses staffed primarily by recent immigrants, many of whom have little English-language capability. In this industry color may be the primary way-if not the only way-to distinguish one product from another. ${ }^{113}$

The Ninth Circuit, in a particularly strange opinion, reversed the district court in part. ${ }^{114}$ The court held that color alone could not be protected under the Lanham Act, noting other courts' concern with color depletion and shade confusion, and accordingly canceled the plaintiff's trademark. ${ }^{115}$ The court proceeded to find, however, that because the defendant had infringed the plaintiff's distinctive trade dress, it would affirm both the plaintiff's money judgment and the order enjoining the defendant from passing off his product as that of the plaintiff. ${ }^{116}$

Significantly, in upholding the trade-dress infringement claim, the Ninth Circuit noted that the defendant's use of the plaintiff's distinctive color would likely deceive purchasers: "The degree of care likely to be exercised by the consumer also supported a finding of likelihood of confusion. Qualitex presented

11221 USPQ2d (BNA) 1457 (C D Cal 1991), rev'd, 13 F3d 1297 (9th Cir 1994).

${ }^{113}$ See id at 1457-58. See also DAP Products, Inc. $v$ Color Tile Mfg., Inc., 821 F Supp 488, 494 (S D Ohio 1993), citing Owens-Corning Fiberglas, 774 F2d 116. The court in DAP preliminarily enjoined the defendant manufacturer of a tile adhesive-cType I mastic"-from selling its product in red buckets. The plaintiff argued that the color red was its distinctive trade dress. The court agreed, and noted: "The likely degree of purchaser care is low. Although the contractors who use Type I mastic are sophisticated with respect to the skills required for laying tile, they rely on the distributors who sell them mastic to suggest what product to use." 821 F Supp at 493 . The defendant also apparently copied the plaintiff's red in an attempt to intentionally pass off his goods as that of the plaintiff. Id.

114 Qualitex, 13 F3d at 1305.

115 Id at 1302-05.

${ }^{116}$ Id at 1305. The Ninth Circuit's opinion is also troubling from the standpoint of comity. Although under 15 USC \& 1119 courts outside the Federal Circuit have concurrent jurisdiction to cancel a trademark for any reason that would have precluded initial registration (provided that the mark had not become incontestable under $\S 1119(\mathrm{~B})$ ), application of the "mere color" rule could not have precluded initial registration. The Patent and Trademark Office, where initial registration must occur, is under the jurisdiction of the Federal Circuit, where Owens-Corning Fiberglas is the law. Arguably, the Qualitex panel showed a surprising lack of respect for "a co-equal member of a system of thirteen appellate courts arranged in a single tier." In re Roberts, 846 F2d 1360, 1362 (Fed Cir 1988). 
evidence that many purchasers do not speak or read English well." $" 117$

Courts sometimes have looked to purchasers' relative degree of knowledge when deciding whether a mark should be protected. Lanham Act protection has been denied when the court viewed purchasers as especially sophisticated. ${ }^{118}$ Similarly, where different groups of purchasers possessed different amounts of knowledge about the product in question, courts have tailored the amount of Lanham Act protection to suit the disparity in sophistication. In Bayer Co., Inc. $v$ United Drug Co., for example, the court held that "aspirin" was a generic term with respect to lay purchasers, but not with respect to pharmacists and physicians. ${ }^{119}$ Professionals knew that "aspirin" meant Bayer Co.'s particular brand of acetyl salicylic acid; lay people did not, nor had they any need or desire to know. ${ }^{120}$

\section{APPLICATION OF DisTINCTIVENESS DOCTRINE TO NONTRADITIONAL SIGNIFIERS}

The distinctiveness doctrine, as originally set forth in Abercrombie \& Fitch, serves as a useful method of ordering the various concerns and factors discussed above. Like words, colors can be classified as generic, descriptive, suggestive, or arbitrary. Application of the Abercrombie \& Fitch test may avoid some of the difficulties the functionality analysis poses, particularly the proper scope of the aesthetic functionality doctrine. ${ }^{121}$

\section{A. Generic Colors}

A generic color would be one that is so common in a particular context that it serves to identify the product in only a general sense. A generic signifier identifies not the particular product

117 Qualitex, 13 F3d at 1305.

118 See, for example, Pignons S.A. de Mecanique de Precision v Polaroid Corp., 657 F2d at 482, 489 (1st Cir 1981) ("Those most likely to buy an expensive, sophisticated camera in a specialty camera store are also least likely to be confused by any similarities in Polaroid's and Pignons' marks.").

119272 F 505 (S D NY 1921).

120 See id at 510-14. See also Chas. Pfizer \& Co. $v$ Generic Formulae, Inc., 275 F Supp 421, 423 (E D NY 1967) ("Terramycin" challenged; held not generic because purchasers were medical professionals who associated name with source).

${ }_{121}$ McCarthy suggests that the functionality question in the drug-coloring cases can be avoided by simply determining whether the color identifies the type of drug or whether the color identifies the particular manufacturer. See McCarthy, 1 Trademarks and Unfair Competition $\S 7: 21$ at 226 (cited in note 29). See also text accompanying notes 33-35. 
signified, but the class into which the signified product falls. Consider a truck painted fire-engine red. The color red indicates only that the truck is a firefighting vehicle (if it is, in fact, such a vehicle); the color does not tell us who made the truck. Nor, strictly speaking, is fire-engine red a functional color. Other colors are, in fact, better than fire-engine red for emergency vehicles, in terms of immediate visibility. ${ }^{122}$

Whether a color is generic depends to a large degree on prior product marketing and on accidents of culture. Decaffeinated coffee, for example, is associated with the color orange ("Sanka orange") in many parts of the United States, but is associated with red in Europe. ${ }^{123}$

Just as verbal trademarks can become generic, and therefore lose their trademark protection, so too can color trademarks, "no matter how much money and effort the user [or creator] of a generic term has poured into promoting the sale of its merchandise and what success it has achieved in securing public identification." In American Hospital Supply $v$ Fisher Scientific Co., the plaintiff began selling orange biohazard bags at a time when all other manufacturers made clear bags. ${ }^{125}$ The plaintiff also introduced a "Think Orange!" marketing campaign to create interest in his new and "arbitrarily"-colored product. ${ }^{126}$ Over time, however, orange became universally recognized within the medical profession as identifying receptacles for biohazardous medical waste. When the plaintiff sued a competitor for infringement approximately fifteen years after the bags were first introduced, the court refused to allow the claim, because orange, even if once an arbitrary choice of color, had come to symbolize the type and function of the product on which the color appeared:

122 Robert Pierre, Fire Engine Red-or Maybe Yellow, or Even Black, Wash Post M1 (Apr 29, 1993), quoting Peter A. Piringer, spokesperson for Prince George's Fire Department. See also Southamstar Network, Look! A Real Red Fire Truck, Toronto Star A5 (Aug 6, 1992), quoting Windsor Fire Department Chief Earl Turpin-Carroll ("Meanwhile, warning-device technology has advanced to the point where the color of the vehicle is really insignificant. Very bluntly, if you can't see a vehicle with all these lights and warning devices, then you'd have to be blind." "). If the trend toward yellow fire engines continues, then perhaps in ten or twenty years most people will consider yellow to be the generic fire truck color. The term "fire-engine yellow" already conjures up a certain image in those communities with yellow emergency vehicles. See David Knorr and Doug Fast, Local Courier Hopes to Tap Statewide Network, Grand Rapids Bus J T-3 (June 15, 1987).

123 See Favre and November, Color and und et Communication at 158 (cited in note 85).

124 Abercrombie \& Fitch, 537 F2d at 9.

1251988 US Dist LEXIS 11000, *4-5 (N D Ill).

128 Id. 
"Although it may have at one time been at least arguable that AHSC [the plaintiff] had a trademark interest in its orange bags, it is clear that by the time this lawsuit was filed, orange was definitely associated with the functionality of the bag lby symbolizing biohazard]."127

Although the court used the rhetoric of functionality, the facts of the case may more appropriately be viewed through the lens of Abercrombie \& Fitch. Orange on the biohazard bag is functional in the same way that all generic marks are functional; it "refers, or has come to be understood as referring, to the genus of which the particular product is a species." ${ }^{128}$

Judge Bissell, dissenting in Owens-Corning Fiberglas, may have been trying to make a genericization argument in noting that some consumers would not buy fiberglass insulation unless it was pink. ${ }^{129}$ The implied argument is that pink has become so synonymous with residential fiberglass insulation that it no longer identifies that a particular piece of insulation comes from a particular source (Owens-Corning), but simply that the insulation is made out of fiberglass and designed for home use. ${ }^{130}$

\section{B. Descriptive Colors}

If not generic, a color may describe one important aspect of the product. ${ }^{131}$ This function of color is especially important in food products. Brown shades, for example, often signify a chocolate flavor; green and yellow shades may signify a citrus flavor. ${ }^{132}$ The color of a food product may also signal some of its other vital aspects. In AmBrit $v$ Kraft, Inc., the Eleventh Circuit refused to uphold an injunction barring use of royal blue on the

127 Id at *36. See also Norwich Pharmacal Co. $v$ Sterling Drug, Inc., 271 F2d 569, 572 (2d Cir 1959).

${ }^{128}$ Abercrombie \& Fitch, 537 F2d at 9.

120774 F2d at 1130 (Bissell dissenting).

130 Pink insulation's genericization may be upon us. A Commonwealth Edison brochure discussing how homeowners can reduce their utility bills shows a man installing pink insulation. The brochure does not identify Owens-Corning, nor does it suggest that Owens-Corning makes the best insulation, but implies that insulation is naturally pink. Commonwealth Edison, This Winter Warm Your World More Efficiently (1993) (on file with U Chi L Rev). See also Deere \& Co. v Farmhand, 560 F Supp 85, 95-98 (S D Iowa 1982), implying that if farm equipment is not green, it is not really farm equipment.

${ }^{131}$ Remember, too, that even if generic in one context, a color might not be generic in another. "A term may thus be generic in one market and descriptive or suggestive or fanciful in another." Abercrombie \& Fitch, 537 F2d at 10.

${ }^{132}$ See Favre and November, Color and und et Communication at 27-30 (cited in note 85). 
packaging for a chocolate-covered ice cream bar. ${ }^{133}$ In this case, royal blue functioned as a descriptive mark, not a generic mark, since the color does not signify "ice cream," but rather "cool and pleasant": "Royal blue is a 'cool color'; it is suggestive of coldness and used by a multitude of ice cream and frozen dessert producers. $" 134$

The court refused to state categorically that royal blue could never be protected, but instead held that any order enjoining use of the color "must be tailored to achieve the goal of protecting the consuming public from confusion." ${ }^{135}$ By finding that a manufacturer could prevent a competitor's use of a descriptive color to the degree necessary to prevent confusion in the minds of purchasers, the court implied that existence of secondary meaning would be one factor to be weighed in determining the likelihood of purchaser confusion.

AmBrit illustrates the difficulty of drawing a line between generic and descriptive signifiers-especially regarding nonverbal marks. Nevertheless, the line can (and should) be drawn pursuant to the Abercrombie \& Fitch categorization. Because ice cream is not always (or nearly always) signified by blue, blue is a descriptive, rather than a generic mark.

\section{Arbitrary, Fanciful, and Suggestive Colors}

Arbitrary and fanciful color marks are easier to define. A fanciful color is a created color, one that would be wholly unfamiliar to the average purchaser, at least prior to its application to the intended product. Qualitex's greenish gold "brass \# 6587" is a good example of a fanciful color. An arbitrary color is one that, although familiar, is unfamiliar and unexpected in the particular setting. Owens-Corning Fiberglas's cotton-candy pink, as applied to insulation, should be seen as arbitrarily chosen, since cotton candy has little, if anything, to do with insulation.

What, then, would be suggestive use of color? Perhaps a suggestive color would be one familiar in one setting, but used in a different, but related setting. The color would be used not to describe an aspect of the product, but to create an association in the mind of the purchaser between the product and another item. If a Dalmatian breeder, for example, were to use fire-engine red 
in her promotional materials, the color would not describe what her dogs were like, or what they would do. The color would, however, cause potential purchasers to make an intuitive leap: both this color and these dogs are commonly associated with fire trucks. The color choice is neither entirely arbitrary nor entirely descriptive, but the choice is distinctive enough such that it should be entitled to protection under the Lanham Act. Perhaps similar suggestive use of color would be a travel agency's adopting a "sunshine yellow," an exam preparation course's adopting an "operating-room green," or a messenger service's painting its delivery trucks an atrocious lime yellow..$^{136}$

\section{CONCLUSION}

This Comment has advanced an argument for the equal protection of colors in the trademark context. The text of the Lanham Act admits of no formalistic restrictions-such as the "mere color" rule- on the range of symbols that warrant trademark protection. Furthermore, humans' ability to recognize and distinguish an immense number of colors should put the color depletion theory to rest. Finally, protection of "mere color" is often necessary to guard against purchaser confusion, as in the Owens-Corning or Qualitex context. Because nonverbal signifiers are effective and sometimes necessary tools of communication, the law should prevent their misuse just as it prevents the misuse of verbal signifiers. To evaluate whether a given color should receive trademark protection, courts should use the Abercrombie $\&$ Fitch distinctiveness test. The test can also inform the proper scope of such protection.

Although this Comment has primarily focused on the shortcomings of the "mere color" rule, the same analysis may be applied to anachronistic arguments against granting Lanham Act protection to other nonverbal signifiers. In all cases, the test should be whether granting trademark protection in a given circumstance would appreciably diminish the number of signifiers available to those competitors who wish to use the same type of mark, whether color, sound, scent, texture, or something else.

Consider again In re Clarke and the Plumeria-scented embroidery yarn. A court might ask the following questions in such

136 See Knorr and Fast, Grand Rapids Bus $J$ at T-3 (cited in note 122) ("Image is important to Metro Courier. The company's fleet of splashy, fire-engine yellow delivery vehicles screams for attention."). 
a case: Is the sweet fragrance of rose available to competitors, or will nothing but Plumeria suffice? Can the reasonable nose distinguish between Plumeria and chrysanthemum? Has Plumeria become so closely connected with embroidery yarn in the minds of consumers that they ask the clerk at the sewing supply store for "Plumeria yarn," when they mean to say "embroidery yarn?"

Business understands how rich is the world of symbols. A court should not refuse to apply rules of law to nonverbal symbols simply because the court is used to applying those rules to words. Treating color and words equally under the Lanham Act does more than bring doctrinal consistency to the law; equal protection of color means equal protection of those consumers who use color as a map to guide them through the confusion of the modern market. 